IRSH 66 (202I), pp. I6I-I 80 doi:I0.1017/S002085902 I000I 34

(C) The Author(s), 202 I. Published by Cambridge University Press on behalf of Internationaal Instituut voor Sociale Geschiedenis

\title{
International Monetary Fund Riots or Nasserian Revolt? Thinking Fluid Memories: Egypt 1977*
}

\author{
MÉLANIE HENRY \\ IAAC/EHESS and ERC-DREAM project \\ CHS/Université Paris I Panthéon-Sorbonne \\ Paris, France \\ E-mail: Melan.henry@gmail.com
}

AвSTRACT: In recorded memory, the 1977 uprising in Egypt appears as the end of a cycle. Yet, at an international level, it marks the beginning of a wave of protest against International Monetary Fund measures. In this article, I study how communist memories of the uprising, which are the only ones recorded, have built up a disregard for I977's “immature" insurgents. The article investigates how these narratives can inform us about the history of the uprising and argues that the search for a Cartesian-type collective subject among insurgents limits our understanding of the insurrection. It refers extensively to the Alexandria Arsenal, a state-owned shipbuilding company where the uprising began, and the relationship between this "vanguard" and the rest of the insurgents. It deconstructs the theoretical presupposition of an analogy between insurgents and a Cartesian subject that permeates the sources, and also the concepts of "collective memory" and "moral economy". This leads inevitably to the diagnosis of a defective subject. It favours the concept of "fluid memory" and highlights other "January I $977 \mathrm{s".}$

"What was I977?" is the rhetorical question posed by Ibrâhîm al-Bâz, student and Trotskyist, who was active during the uprising of I 8-19 January 1977 in Egypt, before answering: "It was the last twitch of the dead man". ${ }^{\mathrm{I}}$ Indeed, in terms of recorded memory, 1977 was the final year in a cycle of social and political struggle in Egypt.

Yet, at an international level, I 977 may be seen as a beginning rather than an end. The massive protests of that year, which came shortly after those in Peru in 1976 , began a wave of protest, which has not yet ended, against liberalization measures imposed by the International Monetary Fund (IMF) as a condition for accessing loans. It was the implementation of an IMF recommendation that

\footnotetext{
* I thank Jill McCoy for her translation and the ERC-funded project DREAM for their financial support.

I. Ibrâhîm Al-Bâz, Interview, Io May 2013.
} 
sparked the protests of 18 and I9 January. Public subsidies for twenty-five consumer products were halved "in order to tend towards real prices" and adjust to the rules of neoclassical doctrine. This measure was one of a series of liberal actions put into effect under President Anwar al-Sadat (I970I98I), the most emblematic being the economic open-door policy (the infitâh) of 1975 . The year 1977 closed a period in national history while opening a period at the international level.

This paradox lies at the heart of this article and is resonant with the weak structuring of both academic and militant fields of modern austerity protests. ${ }^{2}$ Reforms are considered to be an international phenomenon, whereas protests are seen as national - or even local. We will see how a "reformist" conception of social change, as examined in the typology of the sociologist Alain Roussillon, ${ }^{3}$ is manifested in the reading of 1977 as an ending. Such a conception is part of a hegemonic discourse that relates to struggles in Egypt, the consequences and gaps of which we will also seek to analyse here.

Marxists and others on the left, those who created this discourse, are indeed at the heart of memories of the event. They were the only established political supporters of the protests. The Islamic movement, which was expanding in the I970s, maintained good relations with President Sadat at the time of the uprising. ${ }^{4}$ The movement was virtually absent from the protests, and there are no recorded traces of its possible involvement. ${ }^{5}$

The majority of protesters were not militants, although communists were accused of conspiracy. The communists defended themselves, thereby generating significant written traces. Some of them also shared their views on the event by writing its history, debating it, translating it into fiction, or recounting their experiences. Beyond the writings I used for the purpose of this research (published trial archives, articles from newspapers and journals, political essays, novels), this article is also based on an oral survey carried out in Alexandria, both an industrial hub and a university town, where the first demonstration took place on I 8 January 1977 after news of the subsidy cuts had spread. My enquiry into the protests in Alexandria confirmed the general tendency to consider I 977 as an end date among militants and beyond.

2. John K. Walton et al., Free Markets and Food Riots: The Politics of Global Adjustment (Oxford, 1994), p. 39.

3. Alain Roussillon, "Réforme sociale et politique en Égypte au tournant des années 1940", Égyte/Monde arabe, 199 (1994), pp. I 8-19.

4. Islamist militants had indeed been released from prison en masse between I97I and 1974 by Sadat to counter the influence of the left. It was not until November 1977 that relations between the Islamic movement and the President became tense over the peace process with Israel.

5. The presence of "religious elements" was witnessed in the attacks on nightclubs in the street of the Pyramids in Giza, Cairo. According to the General Prosecutor, no Muslim Brotherhood members were arrested during the uprising. Ahmad Sâdiq Sa'd, "Hâjatunâ Ilâ Istrâtî̀îya Ishtirâkîya Jadîda. Qirâ’ Thâniyya Fî Ahdâth Yanâyir 1977 [In Need of a new Socialist Strategy. Rereading the Events of January I977]", Al-Râya al-'arabîyya (1988). 
The leftists were imbued with the hopes of independence and social justice that the Nasserian experience had carried since the Free Officers coup in I952, undermined by the 1967 defeat in the war against Israel. The militants maintained over time the idea that these revolts were transitory, and would potentially be replaced by more organized struggles, as in the orthodox Marxist interpretation. ${ }^{6}$ From this standpoint, the 1977 uprising seems too spontaneous, violent, unconscious.

"Consciousness" was the watchword of these militants. The collective capacity of the oppressed to engage in successful protest, which gives their actions direction, depends on consciousness. This also distinguishes individuals who reflect from those who are "driven by their bellies". Thus, movements may fail if they are not fuelled by consciousness. Its centrality supposes an analogy between the collective subject of the protesters and the individual Cartesian subject, master of his consciousness. The Leninist party, the site of remembered struggle and democratic centralism, is built on such an analogy. But applying it to "revolutionaries", the masses who carry out revolutions, as opposed to "revolutionists", 7 the revolutionary militants, generates some blind spots.

This article asks how these militant narratives can inform us about the history of the uprising. Its purpose is to show that the search for a Cartesian collective subject among the insurgents, understood implicitly in both the actors' analysis and in many works of social science, limits our understanding of insurrections. This attempt at deconstruction builds on the idea that an insurrection, like an event, is plural. It considers the diversity and instability of the actors' intentions, both in the moment and retrospectively. To explore the more clouded aspects of the history of insurrection, it is productive to interrogate the resonances of an event with the political contexts that succeeded it.

We begin with the case of the Alexandria Arsenal, a state-owned shipbuilding company whose workers represented the vanguard of Nasserian hopes and who sparked the country's first protest on I 8 January 1977. In combining approaches from social history of industry and conceptual history, we will describe the cultural and intellectual edifices that the world ending in 1977 had been built on. Following this embodied description of the relationship between the vanguard and the insurgents, the article will deconstruct the theoretical presupposition that the collective may be seen as a Cartesian subject, both in the actors' analysis and also in terms of the social sciences. We will see that this analogy leads inevitably to the diagnosis of a defective subject insofar as the insurgents are concerned. This logic, present in the sources, is reinforced by the notion of "collective memory", as well as the concept of "moral

\footnotetext{
6. Walton, Free Markets, p. 3 .

7. Hannah Arendt, On Revolution (London, I963).

8. Maurice Halbwachs, La mémoire collective (Paris, I997).
} 
economy", 9 a determining notion in the study of modern austerity protests. ${ }^{10}$ Finally, the article will highlight other "January 1977s" in the framework of contemporary history. It will favour the notion of "fluid memory", ${ }^{\mathrm{II}}$ as opposed to the too holistic "collective memory" of the event. Distancing the Cartesian reduction of the collective subject that emanates from this methodological pluralism will enhance understanding of the experience of the insurrectional event in two senses: how it was experienced by the participants, and how the event lives on.

\section{ALEXANDRIA'S MARITIME ARSENAL: A SYMBOL}

In 1977 , the problem was that $[\ldots]$ we were running certain demonstrations like the one at the arsenal - the first in the country, we went out at $7 \mathrm{am}$ - and the engineering school that joined them around I I am or noon. These demonstrations were in the middle of others made up of millions of non-political people. There were very few of us [...], so you say, it's a hunger protest, there will be - you know cities -, thugs, needy people, there's going to be damage, etc. You're confused, because you want organized and politicized demonstrations but you find yourself with fire and destruction, where consumer cooperatives are being robbed and people are hungry, because they want to eat, it's only natural. ${ }^{12}$

We will see, beginning with the case of Alexandria's maritime arsenal, how a separation develops between conscious militants and those demonstrators who were driven by hunger, as described by Ibrâhîm al-Bâz in his account of the 1977 demonstrations.

According to police sources ${ }^{13}$ the first protests against subsidy cuts in Egypt began at the Alexandria Arsenal, a maritime factory that exemplified the Nasserian state's ambitions of economic development and social justice. In interviews with former workers and in two works by Ibrâhîm 'Abd al-Majîd, ${ }^{14}$ who was an electrician at the arsenal before becoming a writer,

9. Edward Palmer Thompson, "The Moral Economy of the English Crowd in the Eighteenth Century”, Past \& Present, 50 (1971), pp. 76-1 36.

ı. Walton, Free Markets, pp. 23-54.

I I. The expression is developed from Michel de Certeau's work on the art of memory, understood as a fluid, interactive, and heterogeneous practice of time, space, and history. The Practice of Everyday Life (Berkeley, CA, I988).

I 2. Al-Bâz, Interview, ro May 2013.

13. 'Âdil Amîn, Intifâdat Al-Qâbira Fî̀ I8, 19 Yanâyir 1977. Hawâdith 19 Yanâyir 1977

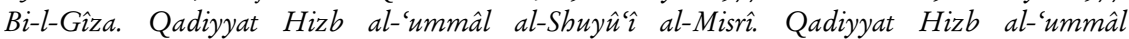

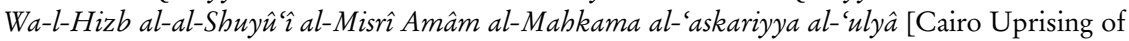
I 8 and 19 January. Events of January 1977 in Giza. The Egyptian Communist Party Case. The Trial of the Workers Communist Party and of the Egyptian Communist Party] (Cairo, 2002), pp. I $5-16$.

I4. Ibrâhîm 'Abd al-Majîd, La Maison aux jasmins (Arles, 2000); Ibrâhîm 'Abd al-Majîd, Mâ Warâ' al-Kitâba. Tajribtî Ma'a-l-Ibdâ' [Behind the Writing: My Experience of Creation] (Cairo, 20I4). 
the shipbuilding company appears as a place where "national consciousness" was performed. The fact that workers at the arsenal initiated the protest reinforces the powerful idea that the demonstrators of I 8 and I 9 January defended the "moral economy" built during the Nasserian period: a broad consensus, defended by the rioters but shared more widely, in the form of a moral contract between rulers and ruled. ${ }^{\text {Is }}$ This moral contract was called into question by the political reorientations undertaken by Sadat. The fact that the arsenal workers were the first to take to the streets on I 8 January confirms their position at the vanguard of a national movement. But the exclusive dimension of this vanguard generates blind spots in our understanding of the 1977 uprising.

\section{On the front lines}

On I 8 January, Mus'ad al-Tarabilî, engineer and communist militant, went to clock on and, as usual, "there were plenty of people, people talking amongst one another”. But that morning, "people stayed, they didn't go to their workshops, they were saying [...] 'we must assert our rights! This action has to be reversed!"'6 Mus'ad and Sayyid Mustafâ ("Berjo"), an electrician at the arsenal, were known locally for their political stance; naturally, the people turned to them. The slogans began to fly thick and fast: "Down with rising prices!" The Prime Minister was targeted by name: "Mamdûh Bey, oh Mamdûh Bey, a kilo of meat has gone to a guinea." ${ }^{17}$

The police report to the prosecutor commented that: "From factory to factory, they encouraged the workers to leave, which they did in small groups. They continued as far as the Bata Society." " 8 The workers then moved towards the city centre, inciting residents and middle- and high-school students to block the street, according to Ibrâhîm 'Abd al-Majîld's novel based on the testimonies of former colleagues, which were collected in the weeks following the uprising. ${ }^{19}$

When they arrived at the Mahmûdiyya canal, which separates the peninsula of Alexandria from the industrial districts to the west of the city, the protesters faced the police, who were barring their route. Determined to continue, they routed the police, and several soldiers were thrown into the water. "The water level under the Chronogram bridge is not very high. They weren't seriously hurt; they did not fall a great distance", said Mus'ad. ${ }^{20}$

I5. Thompson, "The Moral Economy".

16. Mus'ad Al-Tarabilîi, Interview, I6 May 2015.

I7. "Bi-al-rûh, bi-al-dam, hananzil al-as âr"; "Mamdûh Bey, ya Mamdûh Bey, kîlû lahma baqâ bi-gînî.” Ibid.

I8. Amîn, Intifâdat, pp. I ร-16.

I9. 'Abd al-Majîd, La maison, pp. 52-53; Ibrâhîm 'Abd al-Majî̀, Interview, I July 2014.

20. Al-Tarabilî, Interview, I6 May 2015 . 
This first event changed the tone of the popular demonstration. Here and there, there were clashes when central security forces intervened in the protesters' march. Mus'ad confirmed that his march was not responsible for any destruction of public or private property (buses, trams, cars, shops, consumer cooperatives where people used to buy subsidized products).

As in most major cities of the country, the processions marched through Alexandria all day. The police estimated that "at Tahrîr Square in Manshiyya, other workers from other factories joined them, and other individuals from various sections of the population, reaching a total of 10,000 people". ${ }^{2 \mathrm{I}}$

Not far from this square, alongside the consular buildings and the courts, stands the old Alexandria Stock Exchange, which became the headquarters of the Arab Socialist Union, the single party built under Nasser. It was set on fire that day. In Cairo, clubs and luxury hotels in particular, ${ }^{22}$ symbols of the debauchery of the rising élite, were targeted. Slogans denounced the global immorality of the "nouveaux riches", beneficiaries of the economic open-door policy that had been decreed in $1975:^{23}$ "They dress in the latest fashion while we live ten in a room." "They drink whisky and eat chicken while the people starve." ${ }^{24}$

Nasser was omnipresent in the form of a portrait and a slogan, the simple chant "Nasser!". His supporters had been targeted by the "de-Nasserization" of the regime that had been set in motion by Sadat from I97I. ${ }^{25}$ In their chant of "Nasser", the demonstrators were attacking Sadat's policy and legitimizing their own action, putting it under the patronage of the previous president, a monument of the imagined community.

\section{The maritime arsenal: Symbol of a moral economy}

For the Nasserian system's left wing, which published its views in the journal Al-Talî'a (The Vanguard), the arsenal was a spearhead. In I96I, at the beginning of the so-called socialist period, Nasser had made up for the lack of intellectuals in the ruling technocracy by freeing qualified communists from those with the most cultural and social capital. They provided ideological support

21. Amîn, Intifâdat, pp. I 5-16.

22. Sa'd, "Hâjatunâ".

23. Yoichi Nakashima, "The Political Understanding of Al-Infitâh al-Iqtisâdî: A Case Study of Economic Liberalization in Egypt", IMES Working Papers Series, I 2 (Tokyo, 1987).

24. "Malaff Ahdâth I 8 wa ig Yanâyîr [File of the Events of I 8 and I9 January 1977]", Al-Anbâ", December 1980.

25. On is May i97 I, Sadat declared the "Corrective Revolution”. Alain Roussillon, "Republican Egypt Interpreted: Revolution and Beyond”, in M.W. Daly (ed.), The Cambridge History of Egypt (Cambridge, 1998), pp. 334-393. 
for the country's development in $A l-$ Talî $^{\wedge},{ }^{26}$ where they called for the deepening of socialist logic, forging the "leftist" position. Mus'ad, who "could have been a technocrat", ${ }^{27}$ fitted in well with this trend.

"This is not the story of a normal business, it is the story of the hope of the nation!”" ${ }^{8}$ summarized 'Abd al-Majîd, speaking of the arsenal. The techniques implemented in the state-owned business were developed in connection with the Soviet Union, and each year, a group of technicians and engineers spent nine months in Ukraine. With the 1977 protests, the arsenal workers were defending the "common good", as they also did by providing their share of industrial development.

Initially, I believed that there was a tradition of collective action at the arsenal, similar to that at the Helwan weapons factory, the other place where demonstrators emerged in the early morning on 18 January. ${ }^{29}$ Its workers went on strike in 1968 to protest against the light sentences given to air force generals who were convicted of military misconduct in the war against Israel in 1967. On 21 February 1968, the same workers sparked off a large-scale protest, which included universities in particular. ${ }^{30}$ In the early days of my investigation, I learned of memorable demonstrations organized by Alexandria's port workers in 1970 and 1974. They had insulted Sadat at the gates of his Alexandrian palace. In reality, the social status and protest techniques of these persons were at complete odds with those of the maritime arsenal's employees: they were dockworkers from the city's port. Untrained, older, newly arrived from their villages, or fleeing court sentences, the dockworkers were paid by task and had neither health insurance, nor paid leave. $^{\text {I }}$

The arsenal workers, on the other hand, stood out in the industrial district of Qabbârî as being highly skilled and valued both symbolically and materially. "I saw workers elsewhere, but they never had the consciousness of those at the arsenal", said Mus'ad. The company had been established in I96I, but eight years of preparation were necessary before the skilled labour and infrastructure were in place so that production could begin. Participants in a nascent collective, the 5,000 arsenal workers belonged mostly to the same age group, something that contributed significantly - according to

26. Roel Meijer, The Quest for Modernity: Secular Liberal and Left-Wing Political Thought in Egypt, 1945-1958 (London, 2002).

27. Sayyid 'Berjo' Mustafâ Farrag, Interview, 26 May 2015.

28. 'Abd al-Majî̀, Mâ Warâ' al-Kitâba, p. 64.

29. Amîn, Intifâdat.

30. Ahmed Abdalla, The Student Movement and National Politics in Egypt, 1923-1973 (Cairo, 2008), p. I 49.

3 I. Fathallah Mahrûs, Interview, I 3 June 20I 5 . He advised a strike leader and wrote an article on these struggles in an issue of the Communist Workers Party newspaper, the Intifâd. 
Mus'ad and Sayyid Berjo - to a feeling of community and general good relations. They were also close socially, as Mus'ad recalled:

People got along, even engineers and laborers. There were friendships you would not have found in other places, where the engineers had to pay for their studies. Before Nasser, I could not have gone to school, [he] set up free education. You had people who came from the working classes, which ensured better relations with the laborers; there was no condescension or class-based tensions. ${ }^{32}$

The workers benefited from all the symbolic rewards of the Nasserist system: both "workers and artisans", 33 "well dressed and well educated", 34 they were famous in Alexandria. As a result, they worked "in a state of mind one only finds in armies at war". ${ }^{35}$

When conflicts emerged, they were settled within the work units - as they were minor and had to do with production-related issues. Well paid, highly valued, and part of a collective intelligence, the arsenal workers were the envy of Bata labourers and those of the oil industry. The arsenal's workforce had no reason to complain, explained Mus'ad. This, added to their "education", made possible what Mus'ad called "high consciousness": "with them, we could go beyond economic issues, we could talk about more than just stomach aches". ${ }^{36}$

\section{Above and beyond "stomach aches"}

This inferiority of "sector-specific demands" vis-à-vis "general demands" is a characteristic feature of workers' protests under Nasser, as exemplified by industrial wage strikes. To make themselves heard, workers maintained and even increased production rates, but refused to receive their wages. ${ }^{37}$ The Trade Union Federation of Industrial Workers, created in 1957, the only union that structured workers, was designed to organize work in corporate terms rather than being contentious in its demands..$^{8}$ Workers and rural labourers formed a group that contributed to political decisions through making up fifty per cent of the National Assembly membership. ${ }^{39}$ Through this, the Nasserist system institutionalized the political participation of workers and peasants,

32. Al-Tarabilî, Interview, I6 May 20 I 5.

33. Abd al-Majî̀, Mâ Warâ' al-Kitâba, p. 64.

34. Ibid., p. 68.

35. Ibid., p. 64 .

36. Al-Tarabilî, Interview, I6 May 2015.

37. Fathallah Mahrûs, Interviews, June-July 20 I I Françoise Clément, "Péripéties et vicissitudes de la libéralisation du marché du travail en Égypte”, Égypte/Monde arabe, 20 (I994), I43-I 53. 38. Robert Bianchi, Unruly Corporatism: Associational Life in Twentieth-Century Egypt (New York, 1989).

39. Assef Bayat, "Populism, Liberalization and Popular Participation: Industrial Democracy in Egypt", Economic and Industrial Democracy, I 4: I (1993), pp. $65-87$. 
neutralizing social conflict. At the same time, any political acts apart from those that had been agreed by the regime were strongly repressed, which reduced the scope of potential action and redefined what was thinkable and what was unthinkable for political opposition groups, including the communists.

Nasser's policy was thus part of a "reformist thinking" of the social question: in conceptual, institutional, and social terms, it correlated the question of identity (ethnic, religious, or cultural) with that of knowledge and selfreform. This depoliticization of social change had been spreading through a range of political trends since the I940s. Social policies were implemented with the overall aim of addressing all aspects of "Egyptian backwardness": spiritual; economic; legal; and even sanitary. Egypt was only one specific application of a universal programme. From this interpretative framework, based on European standards of "modernity", various intellectuals have assigned themselves a "critical function", both from the viewpoint of the colonial enterprise and from that of "indigenous' responsibilities". ${ }^{\circ}$

This conception of social change permeated Mus'ad al-Tarabilî’s pronouncements, and gave the arsenal workers and students, who made generalized national claims in 1968 and 1972-1973, their status as the "vanguard" of the movement. The rest of the people who took to the streets on i 8 January I 977 were "backward", "driven by their bellies".

In essence, this is the context of the 1977 uprising, which was rooted in hopes of independence and the Nasserian regime. That the Alexandria maritime arsenal acted as a driving force - the spearhead of modernity - in the I 977 uprising produces an effect of over-representation. Their model performance of the Nasserian moral economy makes sense when one considers their work experience as equivalent to an incorporation of the Nasserian state. They are the "vanguard" of the uprising, the metonymic receptacle of its consciousness.

\section{THE INSURGENTS: A FAILING SUBJECT}

The distinction between "conscious" militants and "unconscious" insurgents was a theme surprisingly shared by the supporters and detractors of the 1977 uprising. The regime denounced a communist plot that allegedly manipulated the masses. Leftists, authors of the memories of the event, defended their position, describing insurgents who were driven by social forces and unaware of their actions. The analogy between the Cartesian subject - endowed with duties, power, and knowledge - and the insurgent collective has long been a paradigm common to government and to Communists. In this reading, the insurgents appeared to be a "failing subject". This bias, consubstantial to the genesis of the sources, can be reinforced by later observers, based on

40. Roussillon, "Réforme sociale”. 
their use of the notions of "moral economy" and "collective memory" in their study of insurrections.

\section{The "unconsciousness" of the insurgents}

In a statement of 29 January I977, Prime Minister Mamdûh Bey blamed the violence on an "insurrection of thieves" and on "communist elements wishing to manipulate the demonstrations by leading them to the public square and desiring to take control of the masses". ${ }^{4}$ In the Egyptian press on 23 and 24 January, the involvement of the Soviets in organizing the riots was presented as obvious. ${ }^{42}$ The courts did not hold the militants responsible for planning the events, and national security forces acknowledged that actions had not resulted from political activism. ${ }^{43}$

On the other hand, in the streets, the militants were trying to control the revolt. In Cairo, processions of workers and students came together to demand the withdrawal of measures imposed at the People's Assembly, not far from Tahrîr Square. In Alexandria, police sources mention a meeting with the city's governor. ${ }^{44}$ Experienced militants demanded that protesters should limit their action to slogans and not cause material damage. This advice was sometimes ignored, and the voice of caution was generally overwhelmed.

The first writings on the uprising are by journalist Hussayn 'Abd al-Râziq, a senior member of the National Progressive Unionist Party, which emerged out of the left wing of the former single party that had been disbanded between I 975 and 1977. Râziq's book describes the "underlying causes" and the social forces that led to the "unplanned, spontaneous and global" movement. ${ }^{45}$ Similarly, in The House of Jasmine, Ibrâhîm 'Abd al-Majîd explains the uprising: his account describes the structures that make history. In it, he uses typification, or the process of condensing the character traits of social groups into a single person. This process may be found in fiction, sociology, and history, though each genre gives it a different status. ${ }^{46}$

4I. Hussayn 'Abd al-Râziq, Misr Fî I 8 Wa Ig Yanâyir. Dirâsa Siyâsiyya Wathâ'iqiyya [Egypt on I 8 and I9 January 1977: A Political Documentary Study] (Cairo, I985).

42. Report from the Ambassador in Cairo to the Secretary of State in Washington of 24 January 1977. R 24I43IZ JAN 77. Available from: http://aad.archives.gov/aad/createpdf? rid $=16925 \& \mathrm{dt}=2532 \& \mathrm{dl}=1629$; last accessed 23 February $202 \mathrm{I}$.

43. In reports Io० and IOI on the responsibility of the left in the events. "Malaff Abdâth I 8 wa I 9 Yanâŷे [File of the Events of I 8 and I 9 January I977]”, Al-Anbâ' (December I980), "al-Haqîqa wa-l-Târîkh" [Truth and History], p. 22.

44. Amîn, Intifâdat, pp. I 5-16.

45. Hussayn 'Abd al-Râziq, Misr Fî̀ I 8 Wa I9 Yanâyir, pp. 22-23.

46. Ivan Jablonka, L'histoire est une littérature contemporaine. Manifeste pour les sciences sociales

(Paris, 2014), p. 67. 
Too wrapped up in his physical life, the story's main character, Chagara, is not interested in the politics of his country. ${ }^{47}$ Unbeknown to him, society's ills are nevertheless reflected in his physical and psychological state. On I 8 January 1977, led by others, he is held in a kind of trance by events, and he regains consciousness only at the end of the day..$^{8}$ As such, Chagara stands for a people occasionally experiencing life as a collective group, but generally unaware of itself as a greater unity and only aspiring to prosaic goals (a salary rise, an apartment, etc.). Like a people as a whole, Chagara is driven by his political context. The political leader and the author, however, are conscious of what is taking place. Working, in their eyes, to "elevate the people's consciousness", they assume the insurgents are unconscious players.

The human sciences are not exempt from seeing in the insurgent collective a diminished subject that is made up of "unconscious" subjects. Objectivist analyses that explain insurrections but filter out the insurgents as individuals have been attacked for denying them rationality, as E.P. Thompson shows in his work on the moral economy of the crowd in eighteenth-century England, in which he describes insurgents' agency. ${ }^{49}$ But instead of abandoning the paradigm of the Cartesian subject, the search for a "moral economy" can reinforce it, positing the "rationality" of the rioters. Thompson defended their rationality, as opposed to irrationality, ${ }^{\circ \circ}$ instead of questioning the relevance of the dichotomy. I have used this fruitful concept but question one aspect of it, pointing out that one may be tempted to integrate the insurgent collective to a narrative that does not make explicit that the group is not defined by a set of properties, and indeed is not a Cartesian subject. ${ }^{5 \mathrm{I}} \mathrm{I}$ therefore agree with Achille Mbembe when he argues that the "rediscovery of the subaltern subject", in line with an "outdated Marxist tradition", has too often involved a search for the reflection of material conditions in the "subject's consciousness", leading to a reductive functionalism. ${ }^{52}$ The main problem with this is that it may hinder listening to moral judgements or partisan projections.

47. Al-Majîd, La maison, p. 106.

48. Ibid., p. 58.

49. E.P. Thompson explains that food riots usually arose in response to a regulated practice of protest, the purpose of which was to remind merchants and authorities of an earlier consensus, the paternalistic model, in which benevolence towards consumers was required in the market. The disappearance of these practices in the face of the introduction of modern forms of protest (centralization, industrial working class, party, union) has meant forgetting why they existed to begin with. What remains is "a spasmodic view of popular history" where "the common people can scarcely be taken as a historical agent before the French Revolution": Thompson, "The Moral Economy".

50. For instance, Edward Palmer Thompson, Customs in Common (London, I991), pp. 258, 265, 302,303 .

5. Jacques Rancière, Les mots de l'histoire (Paris, I992), p. 62.

52. Achille Mbembe, On the Postcolony (Berkeley, CA, 200I), p. 5. 
Restoring the forgotten motives of rioters of the eighteenth century or the insurgents of 1977 does not mean that one should construe the motives of the collective formed on the streets as uniform so that it can be analysed - as one would an individual subject. Documenting the creativity of those who have acted consciously is, indeed, to contribute to the history of people's ability to act, as historian John Chalcraft argues. ${ }^{53}$ The creation of groups that are consciously acting collectively is, moreover, congruent with revolutionary situations. Nevertheless, can the study of insurrections be limited to their intentional and conscious dimensions, as if they were all to be considered? Is the insurgent collective's ability to act not also a part of the heterogeneity of a movement in the process of being created? It is essential to take into account this multiplicity to examine the history of resistance to liberalization.

\section{I977, final horizon in "collective memory"}

With his founding notion of "collective memory", ${ }^{4}$ Maurice Halbwachs considers the social conditions of memory production. Individual remembrance is linked to the memory of the social groups with whom experience is shared. This notion can, in turn, reinforce the paradigm of the collective as Cartesian subject and generate certain dead angles, among which is the notion that the 1977 uprising played an exclusively cycle-closing role.

However, the notion of "collective memory", inspired by historian Marie-Claire Lavabre, ${ }^{55}$ reveals a hegemonic discourse on the uprising. The traces of the uprising were emblematic of the memory phenomenon because they contribute to a use of the past as a political resource. Proceeding by chronological, moral, or narrative simplification, relying on imprisonments, strikes, or deaths, the Alexandrian witnesses of the investigation matched their individual narratives with the so-called narrative of the groups to which they had belonged: the workers and/or political militants of the arsenal, the Communists of Alexandria, student militants, and so on. The result was a common chronology that gave meaning to the 1977 uprising. A surprisingly stable "collective memory" was thus at work. The congruence between the events at the arsenal, the insurrection of 1977 , and Nasserian hopes is so striking that it becomes disturbing: this is a result of the event's being analysed in terms of "collective memory". Indeed, the convergence of notions forged around this concept generates coherence and stability in social science narratives. This relationship to culture, consisting of determining its rules rather

53. John Chalcraft, "Thinking Subaltern Activism and Popular Politics in the Middle East and North Africa in Gramscian Perspective”, paper presented at the Gramsci in the Middle East: lessons from subaltern rebellions, Scuola Normale Superiore, Firenze, 2019.

54. Halbwachs, La mémoire collective.

55. Marie-Claire Lavabre, "Paradigmes de la mémoire", Transcontinentales. Sociétés, idéologies, système mondial, 5 (2007), pp. I39-I47. 
than interpreting its signs, makes it impossible to explore the intertwining of meaning in $1977 . .^{56}$

A component of stability, memory was made into a field of political action by communist militants in Egypt from 1995 onwards, the establishment of the Communist Movement Archives Committee until 1965. ${ }^{57}$ This committee collected documentation and witness accounts relating to the communist movement until the pivotal date (1965) when the main communist organizations disbanded in order to lend support to Nasser. This date was later commuted in $1977 . .^{8}$

"Reform thinking" was also part of active remembrance. My interview with 'Abd al-Majîd attests to this. In his novels, he relays the history of the country in accordance with the doxa of the Egyptian literary field. ${ }^{59}$ He assumes this responsibility because he believes that "normal people" do not have memory: their attention is too monopolized by daily obligations: eating; finding shelter; marrying one's children. From this perspective, memory is consciousness. Collective history and individual history occupy parallel worlds that only enlightened beings can bring together.

Following I 8-I9 January, the measures were withdrawn but the great neoliberal disruption continued, producing the change that conferred on the 1977 uprising its status as the end of an era. Ibrâhîm al-Bâz:

Most people saw in 1977 a rebirth of the movement, a new beginning, and the starting point of a rapid chain of events that would lead us to a revolution. And the truth, what we discovered afterwards, when we stood back and looked at the events, is that 1977 was what? The last twitch of the dead man. ${ }^{60}$

The years 1967-1977 were a period of intensified protest, of increased unofficial trade union militancy, and of a growth in communist organizations. The latter worked hard to increase their presence. The important presence of their slogans in the 1977 demonstrations and the fact that these were regularly reused was a commonly cited signification of their effectiveness. An important moment in the local establishment of communist groups had taken place just a few months before, during the campaign for the legislative elections of 1976, with the independent candidacy of five communists and

56. Clifford Geertz, "Thick Description. Towards an Interpretive Theory of Culture", in The Interpretation of Cultures: Selected Essays (New York, I973).

57. Didier Monciaud, "Un travail de mémoire de la gauche égyptienne", Cahiers d'histoire. Revue d'bistoire critique, 86 (2002), pp. I I 5-I 23.

58. Hannân Ramadân, coordinator of the gathering of additional witness accounts for the Center for Arab and African Research in Cairo, which hosts the committee's research, Interview, 9 May 2013 .

59. Samia Mehrez, Egyptian Writers between History and Fiction. Essays on Naguib Mabfouz, Sonallah Ibrabim and Gamal al-Ghitani (Cairo, 1994); Richard Jacquemond, Conscience of the Nation: Writers, State, and Society in Modern Egypt (Cairo, 2008).

60. Al-Bâz, Interview, Io May 2013. 
many leftist Nasserists. Barely a few months after the events, the president of the Unionist Party, Khâlid Muhyî al-Dîn, said that I 977 represented the departure of the Marxists who were still present in institutions, despite Sadat's efforts to eliminate them. ${ }^{6 \text { I }}$

After his liberation from prison in 1977, Mus'ad al-Tarabilî's whereabouts were strictly controlled. He was arrested again in 1979 , I980, and $198 \mathrm{I} . \mathrm{He}$ stopped fighting in $198 \mathrm{I}$ and went to work abroad, receiving a higher salary for the same job. His journey ended in 20I2, when I met him, on his return from five years spent in China. "I abandoned great hopes in favour of what I could accomplish. I did not want to lose on all fronts, personally and collectively. Rather than great hopes, I focused on what I knew how to do, I trained a lot of people. I built my life." ${ }^{62}$

Increasing emigration was key to the disintegration of the militant world. Thanks to measures put in place under Sadat, it became more common to emigrate: there were about 100,000 workers abroad in 1973 and almost 3 million in $1984^{63}$ Families also relied more frequently on the resources of a parent who was abroad. ${ }^{64}$

As a result of the 1977 repression and the oil boom, labour demonstrations ceased for a while and did not resume until $1983-1984 .{ }^{65}$ More generally, the conditions for collective action evolved with the arrival of President Mubarak in 1981. Sadat had alienated diverse opponents, as illustrated by the arrest of more than a thousand workers' association, political, and religious figures on 5 September 198I. Mubarak immediately released most of them and softened his relations with intellectuals. He proceeded in the same way with the Unionist Party, the legal left, which was increasingly favouring stability over protest. ${ }^{66}$ Clandestine communist organizations languished, sometimes preferring militant actions in "civil society" ${ }^{67}$

The frozen aspect of memories of the events of I977, like the enduring "haunting" of Nasser ${ }^{68}$ were reinforced by the living conditions and militant

6r. Khâlid Muhyî al-Dîn, "Recenti Sviluppi Democratici in Egitto e l'Assemblea Nationale 1977 Progressista Unitaria", presented at the conference "La Sinistra egiziana e le prospettive del socialismo nel mondo arabo", Rome, 1977, pp. 7-13, quoted by Gennaro Gervasio, Al-Haraka al-Markisiyya Fî̀ Misr 1967-198I [Marxist movement in Egypt 1967-198I] (Cairo, 2010), pp. II $9,240-247$.

62. Al-Tarabilî, Interview, I6 May 2015 .

63. Mostafa Kharoufi, "L'Infitâb' et l'envers du décor”, Tiers-Monde, 31:I 2 I (I990), pp. 209-2 I 5.

64. Proof of this may be found in the massive increase of currency transfers into Egypt. Sixty-nine million dollars in 1973 became 3.9 billion dollars in 1984 . Kharoufi, "L"Infitâb'.

65. Omar El Shafei, Workers, Trade Unions and the State in Egypt, I984-I989 (Cairo, 1995).

66. Marsha Pripstein Posusney, Labor and the State in Egypt, 1952-1994: Workers, Unions, and Economic Restructuring (New York, 1997), p. 36.

67. Dina El Khawaga, "La génération seventies en Égypte. La société civile comme répertoire d'action alternatif" in Mounia Bennani-Chraibi et al. (eds), Résistances et protestations dans les sociétés musulmanes (Paris, 2003).

68. Sara Salem, "Haunted Histories: Nasserism and the Promises of the Past", Middle East Critique, 28:3 (2019), pp. I-17. 
life in the I980s and I990s, by the memory initiatives undertaken by communist militants, and by the notion of "collective memory". Because this establishes a close link between a community endowed with memory and subject - in the sense of cogito - the notion of "collective memory" tends to reify social groups. ${ }^{69}$ However, beyond the fact that all groups are always being defined, a wide swathe of the history of the insurrection resides in aspiring and short-lived collectives. Departing from a holistic approach to "collective memory" does not necessarily mean adopting a phenomenological reading of memory linked to individual experiences of the uprising. ${ }^{70}$ On the contrary, the research methodology can be adapted to the fluidity of the uprising and the collectives that make it up.

\section{A MANIFOLD INSURRRECTION}

In order to reveal the other stories of the January I 977 uprising, one has to break with the quest for a single meaning of the event and a self-conscious insurgent subject. This approach may generate an element of chaos, given that it requires the event to be seen from multiple points of view and temporalities: this diversity makes it difficult to prioritize elements of analysis. Sociologist Charles Kurzman affirms that all insurrectional moments share the element of confusion. Confusion, however, is a single horizon only to the extent that the only alternative to a study of the subjective experience of events is an objective study, a search for the causes of revolution. ${ }^{71}$ If we do not wish to apply a holistic and causal approach to writing the history of groups, how is it possible to restore the multiplicity of an event without giving up on producing a consistent historical account?

Instead of contrasting insurgents' perspectives of the event with a teleological reading, which would inscribe the event in a later process that is necessarily unknown to the actors, I prefer to weigh the anchor with regard to the event's future. A history of the manifold event is thus made by jumping back and forth between the eras, ever conscious that it does not have an end point. Subsequent revolts express the elements that were contained in the 1977 uprising: "bread idiom", ${ }^{2}$ democratic expectations, the will to overthrow the regime. These later revolts therefore make it possible to highlight aspects of

69. Jocelyne Dakhlia, L'oubli de la cité (Paris, I990), p. I I.

70. Claude Romano, "La phénoménologie doit-elle demeurer cartésienne?”, Les Études philosophiques, I00:I (20I 2), pp. 27-48; Paul Ricoeur, Memory, History, Forgetting (Chicago, IL, 2009). 7I. Charles Kurzman, "Can Understanding Undermine Explanation? The Confused Experience of Revolution: Systems and Mechanisms”, Philosophy of the Social Sciences, 34:3 (2004), pp. 328-35 I. 72. Mélanie Henry, "Le 'trésor' révolutionnaire. Insurrections et militantismes à Alexandrie en I946 et en 1977 (Égypte)” (Ph.D., Université d’Aix-Marseille, 201 8), p. 227. 
the original event that were previously difficult to describe. This is particularly true of the 20 I I uprising.

\section{A counterpoint to leftist accounts}

As told by the left, the protests of 1977 circumvented partisan and union political intermediation, as did many protests of the neoliberal era. ${ }^{73}$ The protesters did not set up institutions that would allow dialogue and did not intend to take power. What was immature in the eyes of leftist militants was also a rejection, as shown by the avoidance of actions created by official organizations (the General Federation of Egyptian Workers' Unions, the Rally party) and unofficial ones (underground parties and unionists).

On I 8 January, unionists and political protesters reflected a desire to see their powerful demonstrations bear fruit. To do so, they consolidated and institutionalized a space of protest within the sphere of their daily actions. Despite the fact that experienced militants demanded that protesters limit their action to spoken slogans, police stations were set on fire. ${ }^{74}$ The burning of the headquarters of the Arab Socialist Union in Alexandria probably indicated the rejection of the party that controlled all authorized political life.

In the previous two decades, a considerable part of trade union unrest had been conducted in parallel with the official organization, the General Federation of Egyptian Workers' Unions, and was often aimed against it. ${ }^{75}$ However, it was an intervention framework for left-wing activism.

The attitude of the federation towards liberal reforms recalled the ambivalent relation of Communists toward the uprising. ${ }^{76}$ Federation president, Salâh Gharîb, had been in favour of the economic open-door policy in April 1975 , but pressure from left-wing trade unionists had nevertheless led to the adoption of a reduced version of the measures. The "openness" was seen as a necessity for economic growth, but care had to be taken to preserve the "socialist trajectory". 77

On the evening of I 8 January, the federation leadership denounced the government measures. During their first meeting with Sadat since 1973, the

73. Richard Stahler-Sholk et al., "Introduction: Globalizing Resistance: The New Politics of Social Movements in Latin America", Latin American Perspectives, 34:2 (2007), pp. 5-16.

74. Ibid.

75. Bianchi, Unruly Corporatism, p. I43.

76. Gamal Abdel Nasser Ibrahim, "Représentation syndicale et transition libérale en Égypte. Lecture des élections de 1996", Égypte/Monde arabe, 33 (1998), pp. I8 I-223.

77. Protesters succeeded in causing the creation of a committee designed to formulate their recommendations on the Infitâh. In October 1976, the Ethical Code of Unionized Work - formed out of the committee's work - was made public in The Workers, the Federation's weekly newspaper. Marsha Pripstein Posusney, "Labor as an Obstacle to Privatization: The Case of Egypt", in Iliya F. Harik et al. (eds), Privatization and Liberalization in the Middle East (Bloomington, IN, 1992), pp. 85 -105, 83 . 
president agreed in principle to all of their requests and undertook to consult them on all legislation concerning workers. As a result, the 1977 uprising made it possible to reassert the federation's status while consolidating its internal leadership position through repression of the union's left wing. ${ }^{78}$

This tendency to break the rules of dialogue between authorities and representative bodies - a tendency found during the "IMF revolts" as well as during the $20 \mathrm{I}$ I and 2019 uprisings - can be seen as a sign that a new vocabulary is emerging. It may also be seen as a sign of a lack of interest in "democracy" and/or a desire for effective representative democracy and/or a desire for radical regime change.

\section{Open interpretations}

In general, the problem with a teleological reading of the event - and with attributing meaning to any event in a historical chain of events - is that the era in which the actors perceived the event is not considered. Instead of favouring synchronic sources and references known to the actors, one might examine the event from the point of view of its futures. Some features of the event appear retrospectively because they are expressed in fits and starts. The relatively recent character of the 1977 episode, which belongs to a "contemporized past", ${ }^{79}$ makes it possible to use the insurrection's existing presences in order to better grasp it. The break with the political system in 1977 displays several characteristics when compared with subsequent events.

The 2005 and 2017 protests over the price and distribution of subsidized flour suggest that a silent tradition, a "bread idiom", was carried over from the January 1977 uprising. Though the uprising did not curb liberalization, it did lead to government reconsideration of the issue of subsidies as early as I9 January; and this was obviously not forgotten. The case of the 2017 protests is salient. ${ }^{80}$ Limited to a certain number of towns, they had an ordered structure. Government and police managed road blockades calmly, in contrast to the fierce crackdown on all social and political protest after the summer 2013 coup d'état. Since January 1977, the threat of insurrection has been known to all. As such, protesters have hoped they would be heard playing the first notes of the melody: a route to dialogue has been established. This resonance in the twenty-first century reveals a dimension of the 1977 uprising: it

78. Posusney, Labor and the State, pp. $23,25$.

79. Jan Assman and John Czaplicka, "Collective Memory and Cultural Identity", New German Critique, 65 (1995), pp. I25-133, p. I 29.

80. Since a 2014 reform, there have been cards with chips that have allowed holders to access subsidized products, but the system has not yet been implemented throughout the country. There have been consumer complaints that provisioning problems have resulted from the distribution of the cards. 
inaugurated a kind of revolt that is in itself interpellation and negotiation with the state.

The political scientist Larbi Sadiki establishes links between "bread revolts" and "democratic achievements" in the 2000 s when examining cases of "democratization", which he recognizes as fragile, in Sudan (1985), Algeria (1988), and Jordan (1989). Food insecurity, dramatized by the symbol of bread (al-'aish, in Egyptian Arabic, literally meaning life) and engendered by liberal measures, represents a denial of democracy. According to the moral contract of the "bread democracy" widely diffused in the Arab world in the period following independence, the people gave up political rights in favour of social rights: the vote versus bread. Bread protests, that "discontinuous practice of democracy", ${ }^{81}$ herald a period of democratization: bread versus the vote. Circumvention of the regime's rules for the political game resulting from independence thus appears as a desire for democracy that, for Sadiki, assumes the form of representative democracy. This analysis would refer to a reformist - as opposed to a revolutionary - dimension of the 1977 protests.

For a segment of the Egyptian Far Left, the 1977 demonstrators' violent acts prove a radicalism that political militants have been unable to grasp. In his 1988 text, Ahmad Sâdiq Sa'd challenged the criticism of the Unionist party, which he described as "reformist", lagging behind popular radicalism. The same idea is supported by Tamer Wageeh and Hossam el-Hamalawy, both journalists and trained politically in the Revolutionary Socialist Tendency movement, which emerged in the r990s during the break with the Egyptian radical left's history. Though for the Egyptian Communist Party the enemy was limited to "the clientelist wing of the regime", ${ }^{82}$ these militants held that an overthrow of the regime was possible.

In a text published shortly before the protests of 25 January $20 \mathrm{II}$, the intellectual 'Adil al-'Umrî condemned the inability of experienced militants and intellectuals to defend the insurgents' justified recourse to violence. $\mathrm{He}$ distinguished himself from the previously cited authors in saying that "intellectuals - including from the left wing - are incapable of recognizing, much less understanding, that the masses are larger and more powerful than those they imagine". ${ }^{8}$ For al-'Umrî, Marxist and Nasserist intellectuals had accepted the "insurrection's failure because it did not envision toppling the regime and replacing it with a new, acknowledged socialist one" ${ }^{84}$

8 I. Larbi Sadiki, "Popular Uprisings and Arab Democratization", International Journal of Middle East Studies, 32:I (2000), pp. 71-95.

82. Hossam El-Hamalawy, "I 977: The Lost Revolution" (Cairo, 200I).

83. 'Âdil al-'Umrî, "Qirâ'a Mukhtalifa Li-Intifâdat I 8 Wa I9 Yanâyir" [Another Reading of the Uprising of I 8 and I9 January], Al-Bûsla, 20 I I.

84. Ibid. 


\section{Echoes throughout time}

The period beginning in 20I I brought about a redefinition of Egypt's recent history. Nevertheless, in this troubled context, the hegemonic interpretation remained relatively stable. In view of the deconstruction presented in this article, it appears that these testimonies could be read differently. Instead of a reliable memory, the search for a fluid memory - that is to say, closely dependent on unstable enunciation - could reveal how the present modifies what we perceive from the past.

It was not uncommon for witness accounts to clash. The analogy between I977 and 20I I appeared in various ways: a confusion between eras, an association of ideas bringing about a shift from one to the other, whether explicit or implicit, and even true constructions. The witnesses most attached to an internally coherent narrative were not exempt from the effects, sometimes surreptitious, of present hopes about past experience. ${ }^{85}$

\section{CONCLUSION}

In conclusion, the analogy between the acting group and the Cartesian subject generated a monolithic understanding of the 1977 uprising. From an emic perspective, according to the logic of "reformist thought" in the Roussillon sense, militants who produce sources and workers at the arsenal identified signs of "backwardness" in their compatriots. Though this "vanguard" may have lost its status during the "de-Nasserization" of the state apparatus and the transition to a new "moral economy" from the r 980 os onwards, its ideology has persisted in memories of the event and in a leftist political culture. It even seemed to be emboldened as the world of hope that arose before 1967 sank during the I980s, and the past was converted into militancy in the I990s. From an etic perspective, the notion of "collective memory" reinforces the monolithic character of these readings because it highlights the stable dimensions of memory and is connected to institutionalized collective groups. Thompson's concern with restoring rationality to the insurgents is accompanied by the use of an analogy between insurgents and the conscious subject. It thus perpetuates standards of modern struggles such as the party and the union, making the insurrection appear to be a form of "bankrupt" mobilization.

Through a deconstruction of 1977 as the end of a cycle, this article has sought to point out how to make visible other dimensions of the revolt. I have proposed that we study how eras collide and how fluid memory works on events, all the while considering the futures of events as resources

85. Mélanie Henry, "Fathallah Mahrûs (I936-2016): L’imagination rebelle d'un ouvrier communiste alexandrin”, Égypte/Monde Arabe, I7 (2018). 
to understand their plurality. Retrospectively, this uprising resonated with other historical events, alternately highlighting the desire for democratic reform, the establishment of a "bread idiom" understood by rulers and ruled alike, and even a desire for regime change. These re-readings provide hints towards the competing logics that were contained in the 1977 event.

From 25 January onwards, there was talk of a "revolution" and signs that certain actors wanted to inaugurate. This movement combined a leaderless dimension and extreme fluidity with the affirmation of a revolutionary identity. Indeed, the $20 \mathrm{I}$ u uprising led to the creation of associations, parties, and unions, but, like many of the popular movements of today, it only became institutionalized at its margins. The uproar of the counter-revolution initially reinforced the diagnosis of an absence of "revolutionaries" amid reluctance to engage with the political game. ${ }^{86}$ But the 2019 demonstrations - in Algeria, Sudan, Iraq, Chile, and so on - have, in turn, created a retrospective inauguration point. The power of these movements recalls the possibility of the emergence of a new narrative of the 1977 uprising, which, far from suggesting immaturity, would become a sign of revolutionary approaches to come.

86. Asef Bayat, Revolution without Revolutionaries: Making Sense of the Arab Spring (Stanford, CA, 2017). 